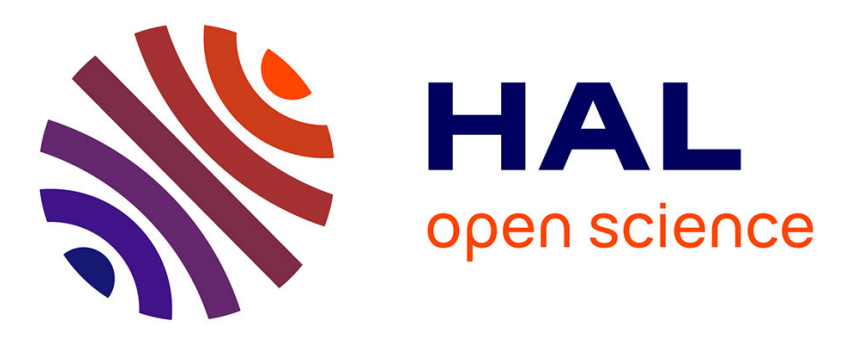

\title{
Biogeochemical processes in sediments of the Manfredonia Gulf (Southern Adriatic Sea): early diagenesis of carbon and nutrient and benthic exchange
}

F. Spagnoli, G. Bartholini, M. Marini, P. Giordano

\section{- To cite this version:}

F. Spagnoli, G. Bartholini, M. Marini, P. Giordano. Biogeochemical processes in sediments of the Manfredonia Gulf (Southern Adriatic Sea): early diagenesis of carbon and nutrient and benthic exchange. Biogeosciences Discussions, 2004, 1 (1), pp.803-823. hal-00297783

\section{HAL Id: hal-00297783 \\ https://hal.science/hal-00297783}

Submitted on 29 Oct 2004

HAL is a multi-disciplinary open access archive for the deposit and dissemination of scientific research documents, whether they are published or not. The documents may come from teaching and research institutions in France or abroad, or from public or private research centers.
L'archive ouverte pluridisciplinaire HAL, est destinée au dépôt et à la diffusion de documents scientifiques de niveau recherche, publiés ou non, émanant des établissements d'enseignement et de recherche français ou étrangers, des laboratoires publics ou privés. 


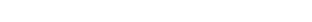

(c) European Geosciences Union 2004

\title{
Biogeochemical processes in sediments of the Manfredonia Gulf (Southern Adriatic Sea): early diagenesis of carbon and nutrient and benthic exchange
}

\author{
F. Spagnoli ${ }^{1}$, G. Bartholini ${ }^{1}$, M. Marini ${ }^{2}$, and P. Giordano ${ }^{3}$ \\ ${ }^{1}$ National Research Council-Marine Science Institute-Departement of Lesina (FG), Italy \\ ${ }^{2}$ National Research Council-Marine Science Institute-Department of Ancona, Italy \\ ${ }^{3}$ National Research Council-Marine Science Institute-Department of Bologna, Italy
}

Received: 22 September 2004 - Accepted: 5 October 2004 - Published: 29 October 2004

Correspondence to: G. Bartholini (gabriella.bartholini@fg.ismar.cnr.it)

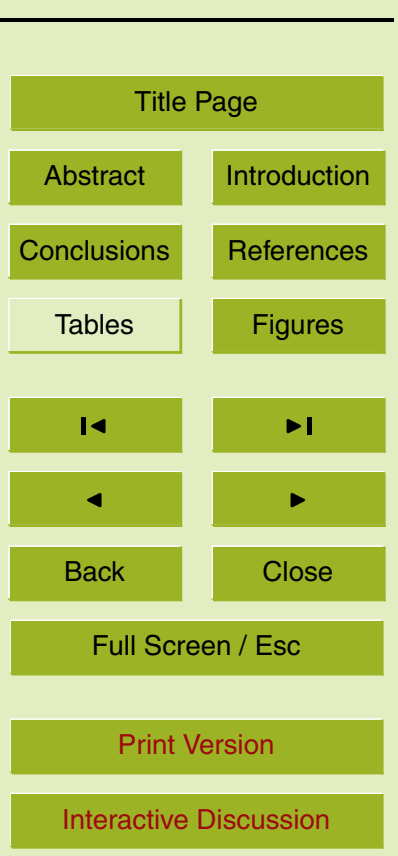

Biogeochemical processes in sediments of the Manfredonia Gulf

F. Spagnoli et al.

(C) EGU 2004 


\section{Abstract}

In order to understand the mechanisms responsible of the recycle of carbon and nutrients at the sediment-water interface and to understand the role of sediments in nutrients mass balance in coastal water, cores were collected (pore waters and solid 5 phases) and benthic fluxes (oxygen, dissolved nutrients, dissolved iron and managanese, alkalinity and $\mathrm{TCO}_{2}$ ) were measured in two stations in the Gulf of Manfredonia (Southern Adriatic Sea). Stations were chosen to include a site, in the offshore part of the gulf, under the influence of western Adriatic current and another site, in the inner part of the gulf, under influence of gyres occurring inside the gulf. Both stations were

terface show higher values in S2 site during the summer. Bio-irrigation seems to be the main transport mechanism characterizing both sites, with more evident effects during summer in $\mathrm{S} 1$ site.

\section{Introduction}

15 The sediment-water interface is a site of intense chemical, physical, and biological reactions, which can lead both to the formation of new phases and alteration of existing minerals and to changes in the composition of waters themselves. The reactions involving the oxidation of organic matter are carried out largely by bacteria using a series of electron acceptors which operate at decreasing redox potentials at increasing depth in the sediment. It is well know that different available terminal acceptors are used by the microbial community in the order of decreasing free energy production per mole of organic carbon oxidized (Froelich et al., 1979; Berner, 1980). These reactions are controlled by external factors, such as temperature, sedimentation rate, organic matter inputs, sea bottom water chemistry and hydrodynamics (Berner, 1980), bioturbation and irrigation. In coastal marine environments with shallow waters and fine sediments, early diagenetic processes play a predominant role in the biogeochemical cycling of
BGD

$1,803-823,2004$

Biogeochemical processes in sediments of the Manfredonia Gulf

F. Spagnoli et al.

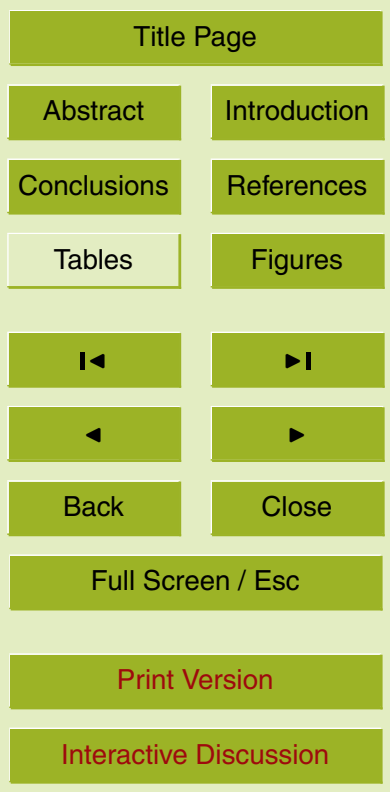

(C) EGU 2004 
nutrients, i.e. they determine the amount of nutrients buried versus the amount of nutrients recycled to the water column as benthic fluxes (Aller, 1980; Giordani and Hammond, 1985; Degobbis et al., 1986; Hammond et al., 1985). Such benthic fluxes can represent an internal input comparable to or higher than external inputs from terrestrial 5 sources (Hammond et al., 1984). Hence, nutrient input and consequently the primary productivity in a shallow coastal ecosystem can be closely associated with sea-floor biogeochemical processes (Cloern, 1996).

The study focuses on the processes that influence the early diagenesis in a shallow basin in southern Adriatic Sea (Gulf of Manfredonia - Fig. 1), where seasonal variation 10 of nutrient inputs and cohexistence of multiple nutrient sources (e.g. nearby rivers or by North Adriatic Currents), can produce seasonal variations of diagenetic processes, and influence quality and quantity of decomposing material.

\section{Study area}

The Gulf of Manfredonia is situated in the western part of Southern Adriatic Sea 15 (Fig. 1). To the North it is delimited by the Gargano Peninsula which morphologically marks the northern border of the Southern Adriatic.

The Gulf is characterized by limited circulation and high sedimentation rate (Damiani et al., 1988; Bianchi and Zurlini, 1984). It represents a transition zone between the Middle Adriatic circulation and the Southern circulation which presents Ionian Sea characteristics, such as oligotrophic waters (Damiani et al., 1988). Recent investigations about surface circulation and current measurements in the Adriatic Sea confirmed a cyclonic circulation in the Southern sub-basin (Poulain, 2001; Kovacevic et al., 1999) characterized by seasonal variability (Poulain, 1999; Artegiani et al., 1997). A cyclonic gyre is often observed in the Gulf of Manfredonia, but may reverse depending on wind

direction (Signell, pers. comm.): cyclonic and anticyclonic gyres are respectively generated by N-NW and S-SE winds (Simeoni et al., 1992).

Biogeochemical properties of the Gulf of Manfredonia are affected by the southward

\section{BGD}

1, 803-823, 2004

Biogeochemical processes in sediments of the Manfredonia Gulf

F. Spagnoli et al.

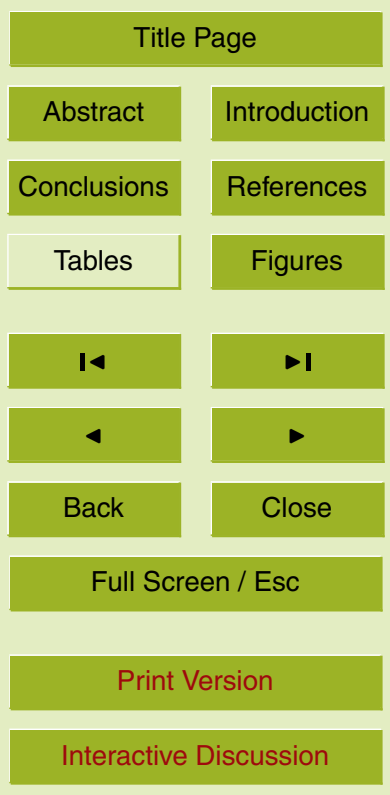

(C) EGU 2004 
coastal current enriched in nutrients (Western Adriatic Current, WAC) flowing along the Western coast of the Adriatic basin. The WAC connects the northern and southern ecosystem and affect of the biogeochemical properties of the whole weastern Adriatic basin. In the Southern Adriatic open waters, however, show clearly oligotrophic char5 acteristics (Vilicic et al., 1989) and the nutrient supply to the euphotic zone depends strongly on the vertical stratification/mixing processes.

Based on grain size analyses in surface sediments 3 sediment types can be recognized: silt sandy, silt and clay. The distribution of these sediment types is essentially the result of wave influence: grain-size in fact decrease with increasing water depth 10 and distance from shore (Brondi et al., 1976; Colantoni et al., 1975). Silt sandy sediments are common in zones adjacent to the shoreline between depth 2-4 $\mathrm{m}$ where wave currents are lower. Silty and clay sediments are found in the central part of the Gulf ( $>8 \mathrm{~m}$ of depth) and in the deeper zones. Bioclastic fragments are found in some coastal sites ( $>6 \mathrm{~m}$ of depth) due to breaking coral reef (Simeoni, 1992).

The average water temperature difference between winter and summer months is approximately $11-20^{\circ} \mathrm{C}$. Water column productivity has been shown to be higher in summer months (Spagnoli et al., 2004a).

\section{Methods}

During two oceanographic cruises carried out in late summer (October 2002) and late 20 sedimentation rate occur using a SW-104 corer, a device which assures the collection
of the undisturbed sediment-water interface. Cores recovered shipboard were sectioned and centrifuged for pore water and solid phase analyses. The water overlying the cores was generally clear, suggesting minimal disturbance, although the sediment

surface was often uneven. Each core was sectioned in a nitrogen-filled glove box on board, and punch in $\mathrm{pH}$ and Eh measurements were made during the sectioning. In order to extract pore waters, the mud was transferred into plastic tubes and

\section{BGD}

$1,803-823,2004$

\section{Biogeochemical processes in sediments of the Manfredonia Gulf}

F. Spagnoli et al.

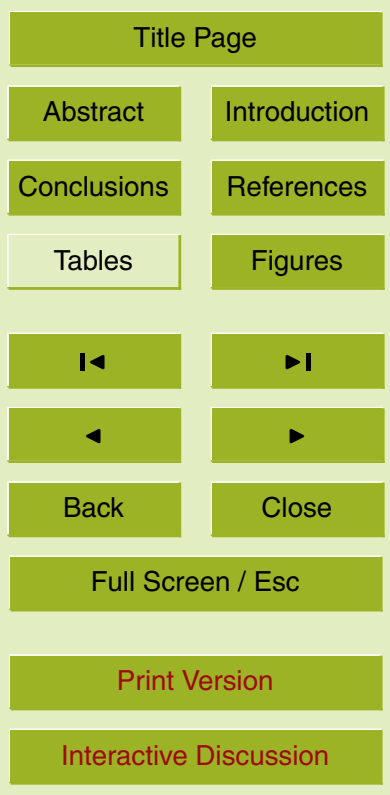

(c) EGU 2004 
centrifuged for about $15 \mathrm{~min}$ at $5500 \mathrm{rpm}$ in a refrigerated centrifuge at near in situ temperatures. Pore waters were filtered under a nitrogen atmosphere through Nucleopore filters $(0.4 \mu \mathrm{m})$ in plastic holders. Four splits were saved unacidified for alkalinity, $\mathrm{TCO}_{2}, \mathrm{DOC}$ and nutrients measurements, and another was acidified (to about pH 1.5) 5 and used to analyse dissolved Fe and Mn. Pore water extraction and filtration was generally completed within 6 hours from core collection. The centrifuged mud was recovered, frozen and subsequently dried at room temperature for analysis of solid phases (organic and total $\mathrm{C}$, total $\mathrm{N}$ ). In the first cruise replicate cores were collected to estimate sedimentation rates and bioturbation coefficients by ${ }^{210} \mathrm{~Pb}$ excess, ${ }^{137} \mathrm{Cs},{ }^{234} \mathrm{Th}$ - measurements. The excess activities of ${ }^{210} \mathrm{~Pb}$ were calculated from ${ }^{226} \mathrm{Ra}$ supported ${ }^{210} \mathrm{~Pb}$ deduced from the activities of ${ }^{214} \mathrm{~Pb}$ and ${ }^{214} \mathrm{Bi}$. Radionuclides were counted using a HPGe (30-60\% relative efficiency, $2 \mathrm{KeV}$ of resolution). In the second cruise replicate cores were collected to measure dissolved oxygen penetration by microelectrode profiler. Sampling and instrumental difficulties prevented us from collecting complete 15 data sets in both surveys.

In situ benthic flux chambers were deployed in each sites. Two chambers were displayed in each site one by side to replicate measurements. Benthic chambers capture approximately $39 \mathrm{I}$ of water in contact with $0.25 \mathrm{~m}^{2}$ of sea bed. Each chamber was sampled six times during deployments of about $24 \mathrm{~h}$. The incubation period of $24 \mathrm{~h}$ was sufficient to generate measurable changes in concentration, but not long enough to produce significant changes in fluxes.

$\mathrm{A} \mathrm{CsCl}$ spike was injected in the incubation soon after the first sampling and the observed dilution of this spike in subsequent sample draws was used to calculate chamber volume and was used as tracer for chamber water exchange with pore water. Chambers were stirred by a rotating paddle such that the diffusive boundary layer thickness within the chamber was unaffected.

Porosity was calculated after drying each sample at $60^{\circ} \mathrm{C}$, total and organic carbon and total nitrogen (all expressed as weight \%) were measured by CHN elemental analyzer (Carlo Erba) after removal of the inorganic carbon with $\mathrm{HCl}$ (Froelich et al., 1979).
BGD

1, 803-823, 2004
Biogeochemical processes in sediments of the Manfredonia Gulf

F. Spagnoli et al.

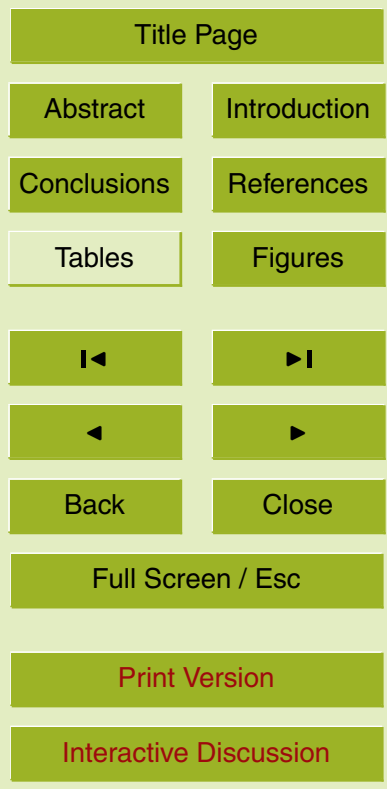

(C) EGU 2004 
Organic nitrogen was assumed to equal total nitrogen (Giordani and Angiolini 1983). Dissolved phosphate, ammonia, nitrite, nitrate and silicate were measured on pore waters and benthic chamber samples by colorimetric autoanalyser technique. Alkalinity was determined by Gran titration (Gieskes and Rogers, 1973) and $\mathrm{TCO}_{2}$ was deter-

5 mined from alkalinity, $\mathrm{pH}$, salinity and temperature. Additionally, in the second cruise, an aliquot of $5 \mathrm{ml}$ was collected for the analyses of $\mathrm{TCO}_{2}$ by manometric measurements (McCorkle et al., 1985). Fe, Mn and Cs were determined on the acidified aliquots by Flame-AAS. $\mathrm{Ca}, \mathrm{Mg}$ and other dissolved cations were determined by HPLC. For each parameters analysed benthic fluxes were calculated as the product of the slope of concentration vs. incubation time and chamber height, without including bottom water data in the calculation. Benthic flux calculations were determined only from the linear portion of the concentration vs. time plots (Berelson et al., 1998) and no flux was reported if we had fewer than 4 data points.

Using two deployment, fluxes were averaged and the uncertainty in the mean was 15 calculated in two ways; (a) as the standard error of the mean; or (b) as the square root of the sum of the variance of each flux value, divided by the number of flux measurements. We report the larger of these two uncertainties, following the procedure described by Hammond et al. (1996).

\section{Results and discussion}

20 4.1. Solid phase measurements

Down-core changes in porosity, ${ }^{210} \mathrm{~Pb}$ activity and organic $\mathrm{C}$ were measured on cores collected. In the study sites surficial sediments have a porosity $0.75-0.8$ and this value decreases to $0.60-0.65$ at 25-30 cm (Fig. 2).

The excess activity of ${ }^{210} \mathrm{~Pb}\left(\mathrm{t}_{1 / 2}=22.3 \mathrm{y}\right)$ (Fig. $\left.3 \mathrm{a}\right)$, decreasing exponentially below 25 the interface in both stations, may be used to estimate the rates of sediment accumulation (Koide et al., 1972). Applying Constant Flux-Constant Supply (CF-CS) model to

\section{Biogeochemical processes in sediments of the Manfredonia Gulf}

F. Spagnoli et al.

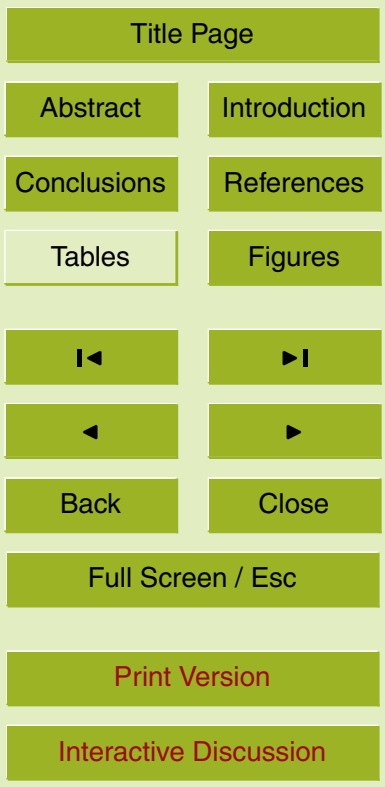

(C) EGU 2004 
the ${ }^{210} \mathrm{~Pb}_{\text {ex }}$ profiles (Lalou, 1982), sedimentation rates $(w)$ from each stations were estimated to be $0.35 \mathrm{~cm}^{2} \mathrm{y}^{-1}$ in station $\mathrm{S} 1$ and $0.43 \mathrm{~cm}^{-2} \mathrm{y}^{-1}$ in station $\mathrm{S} 2$. These values are similar to those calculated by Giordani et al. (1992) and by Hammond et al. (1999) in the Northern Adriatic sea. In order to check sedimentation rates the vertical profile 5 of ${ }^{137} \mathrm{Cs}$ (Fig. 2b) is used. It is well know that a significant input of this radionuclide in the environment occurred in the 1963 related to atmospheric weapon tests. Hence maxima concentrations in cesium vertical profiles correspond to sediments buried in this age (Cochran, 1985), supporting the dating calculated by ${ }^{210} \mathrm{~Pb}_{\mathrm{ex}}$.

Thorium activities were also measured as useful tracer of sediment mixing. The mix10 ing of the upper $10 \mathrm{~cm}$ of sediment caused by macrofauna is referred to as bioturbation, it can alter the physical and chemical properties of sediment affecting both particle and solute transport (Schink and Guinasco, 1977; Rhoads, 1974; Aller, 1980; Aller and Aller, 1986). In order to calculate bioturbation coefficients $\left(D_{b}\right)$ the relation calculated by Pope et al. (1996) was applied to ${ }^{234}$ Th exponential profile (S2 station) and $D_{b}$ was 15 estimated to be $0.20 \mathrm{~cm}^{2} \mathrm{y}^{-1}$. This value falls on the low end of a compilation by Tromp et al. (1995) relating $D_{b}$ to $w$ for similar environments, perhaps because of the episodic presence of low oxygen bottom water. The profiles of ${ }^{234} \mathrm{Th}$ in station $\mathrm{S} 1$ is constant from sediment water interface down to $5 \mathrm{~cm}$, suggesting a bioturbated layer too.

Organic carbon concentrations in all the cores (Fig. 2) rapidly decrease from the 20 sediment-water interface to $5-7 \mathrm{~cm}$, deeper it reaches a low constant value and exhibits a regular trend interrupted only by relatively high values at about $20 \mathrm{~cm}$ in both sites. Total $\mathrm{N}$ concentrations also show a down-core decreasing trend. Continental margin sediments are a mixture of terrestrial and marine components so to identify the source of the organic matter undergoing diagenesis the $\mathrm{C} / \mathrm{N}$ ratio might be used (Froelich et al., 1979). The Redfield ratio of $C: N: P$ in marine sediments, 106:16:1 $(C / N \sim 7)$, might be representative of settled marine phytoplankton, wheras higher values may reflect the breakdown of terrestrial derived particulate organic carbon (POC). The $\mathrm{C} / \mathrm{N}$ average ratios range from $5 \pm 2$ to $7 \pm 2$ in winter and in summer cruise respectively, with higher values shown by surface sediments collected in summer, and similar those calculated

\section{Biogeochemical processes in sediments of the Manfredonia Gulf}

F. Spagnoli et al.

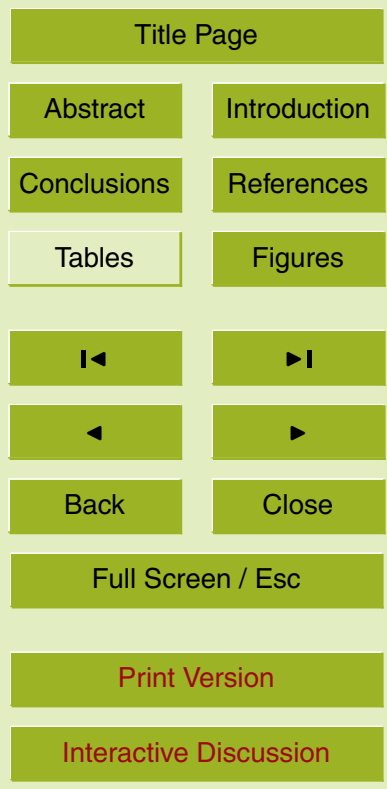

(C) EGU 2004 
in north Adriatic by Hammond et al. (1999). Therefore, the origin of organic matter should be marine.

\subsection{Pore water profiles}

In continental slope and rise sediments underlying well-oxygenated bottom waters, $\mathrm{O}_{2}$ 5 is the most important electron acceptor for organic matter decomposition. In continental margins sediments anoxic conditions occur in few centimeters of depth due to high sedimentation rates and high organic matter inputs. Thus, the sedimentary $\mathrm{O}_{2}$ consumption rate is a good first-order indicator of organic matter oxidation rates in many locations. In the sampled sites dissolved oxygen exponentially decreases below the 10 sediment-water interface and at depth greater than $1 \mathrm{~cm}$ suboxic conditions occur in both sites (Fig. 4). Higher oxygen concentration at the sediment water interface and sharper gradient are displayed at $\mathrm{S} 2$ station.

Pore water $\mathrm{NO}_{3}^{-}$profiles (Fig. 5) show the effects of nitrification in the oxic zone of the sediments and of denitrification immediately below the oxic zone. At sites where we have both $\mathrm{O}_{2}$ and $\mathrm{NO}_{3}^{-}$concentrations, the depth at which denitrification begins is just above or within the depth range over which $\mathrm{O}_{2}$ concentrations reach zero. The $\mathrm{NO}_{3}^{-}$ reaches 0 values depth at about $20 \mathrm{~cm}$. The low, constant, non-zero values observed below $20 \mathrm{~cm}$ at $\mathrm{S} 2$ site are most likely non-zero because of a calibration problem.

Suboxic diagenesis is indicated by the pore water profiles of dissolved manganese and iron (Fig. 6) according to the well-established depth sequence of diagenetic reactions, governed by the preferential use of $\mathrm{Mn}$ and Fe oxide phases as electron acceptors, that yields the highest amount of free energy for the bacterially mediated oxidation of organic matter (Froelich et al., 1979). Dissolved manganese profiles exhibit, in both stations, near surface peaks, just below the oxygen penetration depth. A secondary 25 peak in $\mathrm{Mn}^{2+}$ pore water profile is observed in $\mathrm{S} 2$ site at $13 \mathrm{~cm}$ in summer, deeper the trend continue quite constant. The dissolved Fe shows, in all profiles, a sharp increase just below the depth range in which Mn concentrations reach maxima values, At higher depth dissolved iron concentrations decrease quickly down to $10-20 \mathrm{~cm}$ and then in-

\section{Biogeochemical processes in sediments of the Manfredonia Gulf}

F. Spagnoli et al.

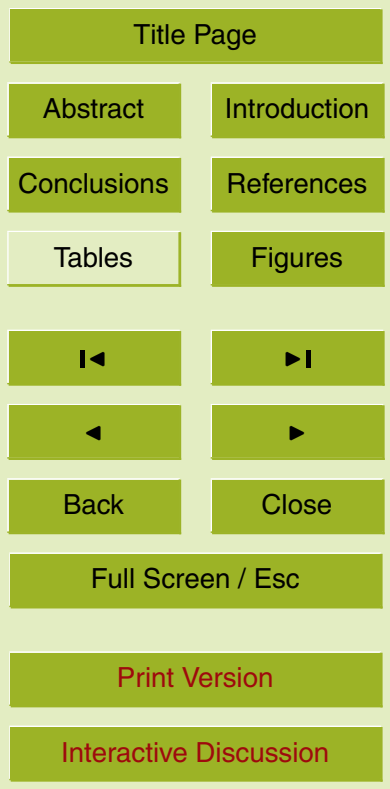

(C) EGU 2004 
crease in both summer cores and in the S2 winter core. The increase of dissolved Fe with depth seems to suggest a complexation with dissolved refractory organic matter, hence any reaction occur with reduced sulphur to form FeS, thermodynamically preferred, or with carbonate, as siderite (Postma, 1982). This is a working hypothesis that 5 needs of further study. The peaks of dissolved $\mathrm{Mn}$ and Fe are attributed to the production of these metals in anaerobic condition by dissimilatory reduction of oxy-hydroxide manganese and iron by bacteria activity: oxide phases may be used as terminal electron acceptors in bacterial oxidation of organic carbon. About the pore water $\mathrm{SO}_{4}$ profiles, the trends are rather constant displaying higher concentrations in the summer 10 profiles in S2 station, hence sulphate reduction does not seem to take place.

The decomposition of organic matter, using $\mathrm{Mn}$ and Fe oxy-hydroxides as electron acceptors below the denitrification layer, results in the release of $\mathrm{NH}_{4}^{+}$and $\mathrm{TCO}_{2}$ into the pore waters. Pore water data (Fig. 5) reflect this process, as they show monotonically increasing $\left[\mathrm{NH}_{4}^{+}\right]$and $\mathrm{TCO}_{2}$ below the denitrification layer. From the sediment-

\section{water interface to $10 \mathrm{~cm}$ of depth, the distribution of both organic matter degradation} products $\left(\mathrm{TCO}_{2}\right.$ and ammonia) is scattered, suggesting bio-mixing and irrigation processes. Activity of macrofauna may deepen and channelize the penetration depth of oxygen and improve solute fluxes across the sediment-water interface. We have not available data on the activities of macrofauna, hence this hypothesis needs further study. The $\mathrm{NH}_{4}^{+}$released to the pore waters by anoxic diagenesis diffuses upwards in the sediment column, where most of it is apparently oxidized before it reaches the sediment-water interface.

The dissolved $\mathrm{PO}_{4}^{3-}$ in pore waters in all cores has a similar trend: a rapid and irregular increase in a layer near surface (about $3 \mathrm{~cm}$ depth), a second relative peak is displayed at about $17 \mathrm{~cm}$, at higher depth the profiles approach the analytical detection limit. The higher value are shown in S1 cores. The irregular trend is due to the complexity of $\mathrm{P}$ cycle: the low concentrations at the sediment water interface are due to the precipitation with $\mathrm{Fe}$ oxy-hydroxides, from the sub-surface to $20 \mathrm{~cm}$ the $\mathrm{PO}_{4}^{3-}$ concentration increase as a result of release by organic decomposition and dissolution
BGD

$1,803-823,2004$

\section{Biogeochemical processes in sediments of the Manfredonia Gulf}

F. Spagnoli et al.

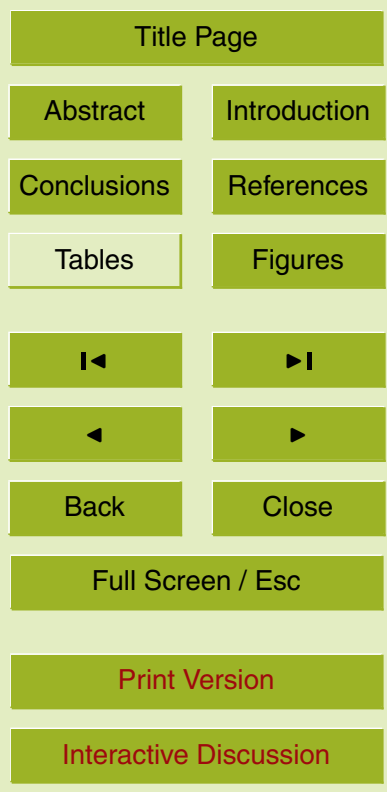

(C) EGU 2004 
of Fe-oxhydroxides and then it decreases because of removal to a sedimentary phase. As a summary, the pore water profiles display a marked seasonality, with degradative processes more intense in the summer period due to higher temperature and higher input of fresh organic matter.

5 4.3. Chamber data

Benthic chamber experiments were successful for the determination of ammonium, nitrate, nitrite, phosphate, silicate, alkalinity, $\mathrm{TCO}_{2}$, manganese, iron, cesium and oxygen fluxes in both sites (Stations S1, S2). As the incubation time increases, there is the possibility that chamber chemistry or other artifacts will produce non-constant fluxes.

10 This is recognizable in some data, so flux calculations were determined only from the linear portion of the concentration vs. time plots and no flux was reported if we had fewer than 4 data points (Berelson et al., 1998).

In Fig. 6 a comparison of benthic fluxes in both seasons is presented. Greatest oxygen uptake occurred in winter in $\mathrm{S} 1$ while in $\mathrm{S} 2$ oxygen uptake was pretty simi15 lar throughout the year. Nitrate flux was always into sediment in S1 site and out of sediment in S2, greatest variability is evident in S2. Dissolved manganese and iron show positive fluxes, stronger seasonality is shown at $\mathrm{S} 1$ site. Ammonia fluxes were always out of sediment, with lowest fluxes occurring in winter, and so behave $\mathrm{TCO}_{2}$ and phosphate. Measured benthic fluxes of degradative organic matter products are 20 significantly higher during the summer in both station, with more significant differences in S2 station.

Actually data on primary productivity are not available, so we are not able to define the seasonal productivity pattern in the Gulf of Manfredonia, however the seasonal variations in benthic chamber fluxes for silicate, nitrate and $\mathrm{TCO}_{2}$ suggest that higher 25 inputs of fresh organic matter occured during summer. The variations are stronger in station S2, where also a different source of organic matter might be present, as suggested by inorganic geochemistry of surface sediments, associated to the material

\section{Biogeochemical processes in sediments of the Manfredonia Gulf}

F. Spagnoli et al.

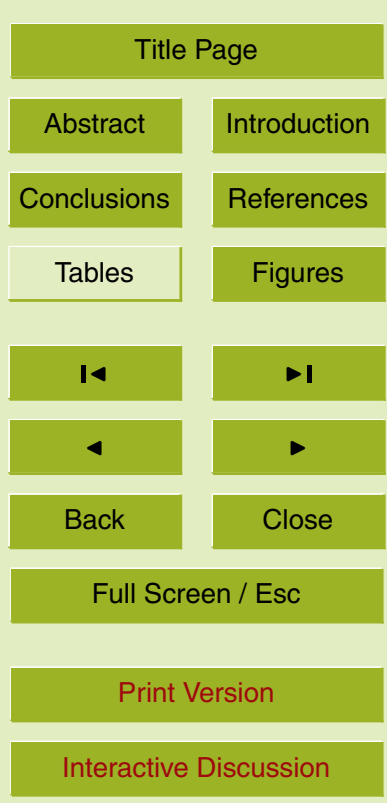

(C) EGU 2004 


\section{Conclusions}

1, 803-823, 2004

Pore water profiles of different electron acceptors for organic carbon oxidation indicate that in the Gulf of Manfredonia diagenesis of organic matter progresses trough oxygen respiration, denitrification, manganese and iron reduction, while sulphate reduction and methanogenesis do not take place. The depth-dependent characteristics of profiles were similar in both sites and seasons. Degradative processes of a prevalently marine organic matter are more intense during summer, as testified by the pore-water profiles and by the increased benthic fluxes of nutrients at the sediment-water interface. The processes of oxidation of organic matter might be influenced by bioturbation and bioirrigation, that are particularly active in the uppermost $10 \mathrm{~cm}$ of the sediment.

Acknowledgements. We wish to acknowledge invaluable assistance in carrying out the cruise from G. Casolino, P. Trentini and R. Belastock provided invaluable assistance in metal and TCO2 analyses respectively. E. Dinelli provided helpful comments that helped refine the final draft. Financial support for this research was provided by the National council of Research trough the PIT AGEM project.

\section{References}

Aller, R. C.: Quantifying solute distribution in the bioturbated zone of marine sediments by defining an average microenvironment, Geochim. Cosmochim. Acta, 44, 1955-1965, 1980.

Aller, J. Y. and Aller, R. C.: Evidence for localized enhancement of biological activity associated with tube and burrow structures in deep-sea sediments at the HEBBLE site, western North Atlantic, Deep-Sea Res., 33, 755-790, 1986.

Artegiani, A., Bregant, D., Paschini, E., Pinardi, N., Raichic, F., and Russo, A.: The Adriatic Sea general circulation. Part I: air-sea interactions and water mass structure, J. Phys. Ocean., 27, 1492-1514, 1997.

\section{Biogeochemical processes in sediments of the Manfredonia Gulf}

F. Spagnoli et al.

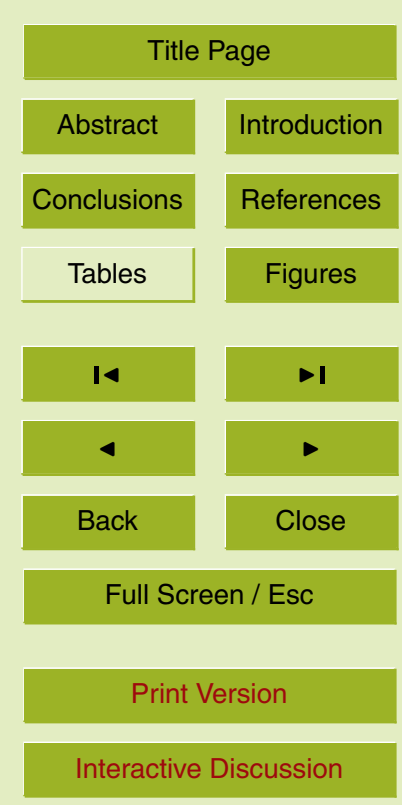

(C) EGU 2004 
Berner, R. A.: Early Diagenesis: A Theoretical Approach, Princeton University Press, Princeton NJ, 1980.

Berelson, W. M., Heggie, D., Longmorec, A., Kilgore, T., Nicholson, G., and Skyring, G.: Benthic Nutrient Recycling in Port Phillip Bay, Australia Estuarine, Coast. Shelf. Sci., 46, 917-934, 1998.

Bianchi, C. N. and Zurlini, G.: Criteri e prospettive di una classificazione ecotipologica dei sistemi marini costieri italiani, Acqua aria, 8, 785-796, 1984.

Brondi, A. and Ferretti O.: Studio sulla dispersione dei sedimenti della piattaforma costera compresa tra Termoli e Barletta mediante l'uso dei detriti della formazione delle "pietre nere" 10 come traccianti naturali, Thalassia Salentina, 12, 87-95, 1976.

Cloern, J. E.: Phytoplankton bloom dynamics in coastal ecosystems: a review with some general lessons from sustained investigation of San Francisco Bay, California, Reviews of Geophysics, 34, 127-168, 1996.

Cochran, J. K.: Particle mixing rates in sediments of the eastern equatorial Pacific: evidence 15 from $\mathrm{Pb}^{210}, \mathrm{Pu}^{239,240}$, and $\mathrm{Cs}^{137}$ distributions at MANOP sites, Geochim. Cosmochim. Acta, 49, 1195-1210, 1985.

Colantoni, P. and Gallignani, P.: Sea floor types and recent sedimentation on the continental shelf between Manfredonia and Trani (Southern Adriatic Sea), Under. Ass. 8th Symposium Polytechnic of North London, 115-118, 1975.

20 Damiani, V., Bianchi, C.N., Ferretti, O., Bedulli, D., Morri, C., Viel, M. and Zurlini, G.: Risultati di una ricerca ecologica sul sistema marino pugliese. Thalassia Salentina,, 18, $153-169$, 1988.

Degobbis, D., Gilmartin, M. Relevante, N. An annotated nitrogen budget calculation for the Northern Adriatic sea. Mar. Chem. 20, 159-177, 1986.

25 Froelich, P. N., Klinkhammer, G., Bender, M. L., Luedtki, N. A., Heath, G. R., Cullen, D., Dauphin, P., Hammond, D., and Hartman, B.: Early oxidation of organic matter in pelagic sediments of the eastern equatorial Atlantic: suboxic diagenesis, Geochim. Cosmochim. Acta, 43, 1075-1095, 1979.

Gieskes, J. M. and Rogers, W. C.: Measurements of total carbon dioxide and alkalinity, J. Sedim. Petr., 43, 272-277, 1973.

Giordani, P. and Angiolini, L.: Chemical parameters characterizing a NW Adriatic coastal area, Coast. Shelf. Sci., 17, 159-167, 1983.

Giordani, P. and Hammond, D. E.: Tecnique for measuring benthic fluxes of ${ }^{222} \mathrm{Rn}$ and nutrients

\section{BGD}

1, 803-823, 2004

\section{Biogeochemical processes in sediments of the Manfredonia Gulf}

F. Spagnoli et al.

Title Page

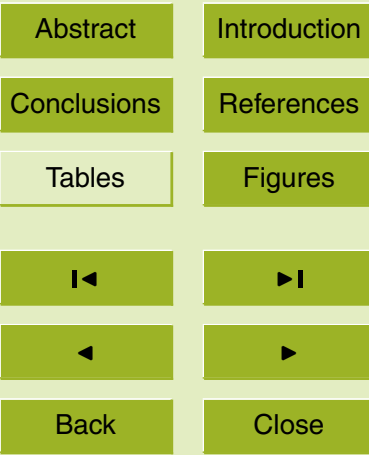

Full Screen / Esc

Print Version

Interactive Discussion

(C) EGU 2004 
in coastal waters, Tech. Rep.. no 20, CNR/IGM, Bologna, Italy, 33 pp., 1985.

Giordani, P., Hammond, D. E., Berelson, W. M., Poletti, R., Montanari, G., Milandri, A., Frignani, M., Langone, L., Ravaioli, M., and Rabbi, E.: Benthic fluxes and nutrient budgets for sediments in the Northern Adriatic Sea: burial and recycling efficiencies, Sci. Total Environ.

5 (Suppl.), 251-269, 1992.

Hammond, D. E., Giordani, P., Montanari, G., Rinaldi, A., Poletti, R., Rovatti, G., Astorri, M., and Ravaioli, M.: Benthic flux measurements in NW Adriatic coastal waters, Mem. Soc. Geol. It., 27, 461-467, 1984.

Hammond, D. E., Fuller, C., Harmon, D., Hartman, B., Korosec, M., Miller, L., Rea, R., Berelson, W., and Hager, S.: Benthic fluxes in San Francisco Bay, Hydrobiologia, 129, 69-90, 1985.

Hammond, D. E., McManus, J., Berelson, W., Kilgore, T., and Pope, R.: Early diagenesis of organic carbon in the equatorial Pacific: rates and kinetics, Deep Sea Res., 43, 1365-1412, 1996.

Hammond, D. E., Giordani, P., Berelson, W., and Poletti, R.: Diagenesis of carbon and nutrients 15

Koide, M., Soutar, A., and Goldberg, E. D.: Marine Geochronology with Pb-210, Earth Planet. Sci. Lett., 14, 442-446, 1972.

Kovacevic, V., Gacic, M., and Poulain, P. M.: Eulerian current measurements in the Strait of Otranto and in Southern Adriatic, J. Mar. Syst., 20, 255-278, 1999.

20

Lalou, C.: Sediments and sedimentation processes, in: Uranium series disequilibrium, edited by Ivanovich and Harmon, Clarendon Press, Oxford, UK, 384-406, 1982.

McCorkle D. C. and Emerson S. R.: the relationship between pore water carbon isotopic composition and bottom water oxygen concentration, Geochimica et Cosmochimica Acta, 52, 1169-1178, 1988.

Pope, H. P., Demaster, D. J., Smith C. R., and Seltman H.: rapid bioturbation in equatorial Pacific sediment: evidence from excess ${ }^{234}$ Th measurements, Deep Sea research II, 43, 1339-1364, 1996.

Poulain, P. M.: Drifter observations of surface circulation in the Adriatic Sea between December 1994 and March 1996, J. Mar. Syst., 20, 231-253, 1999.

30 Poulain, P. M.: Adriatic sea surface circulation as derived from drifter between 1990 and 1999, J. Mar. Syst., 29-32, 2001.

Schink, D. R. and Guinasso, N. L. J.: Redistribution of dissolved and adsorbed materials in abyssal marine sediments undergoing biological stirring, Am. J. Sci., 278, 687-702, 1977.
BGD

$1,803-823,2004$

Biogeochemical processes in sediments of the Manfredonia Gulf

F. Spagnoli et al.

Title Page

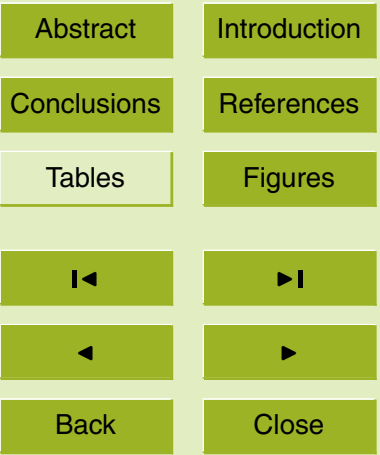

Full Screen / Esc

Print Version

Interactive Discussion

(c) EGU 2004 
Simeoni, U.: I litorali tra Manfredonia e Barletta (Basso Adriatico), Dissesti, sedimenti, problematiche ambientali. Boll. Soc. Geol. It., 111, 367-398, 1992.

BGD

Spagnoli, F., Fiesoletti, F., Specchiulli, A., Bartholini, G., Conversi, A., and Decembrini, F.:

$1,803-823,2004$ Biochemical Processes, Trophic Status And Water Mass Characteristics In The Gulf of Manfredonia (Southern Adriatic Sea), Geophysical Research Abstracts, 6, 06095, 2004a.

Spagnoli, F., Bartholini, G., Grosso, G., Specchiulli, A., Fiesoletti, F., and Dinelli, E.: Geochemistry of Major and in trace element in sediments of the gulf of Manfredonia: an assessment of metal pollution CONISMA, 2004b.

Tromp, T. K., Van Cappellen, P., and Key, R. M.: A global model for the early diagenesis of organic carbon and organic phosphorus in marine sediments, Geochim. Cosmochim. Acta, 59, 1259-1284, 1995.

Vilicic, D., Vucak, Z., Skrivanic, A., and Grzetic, Z.: Phytoplankton blooms in oligotrophic open South Adriatic waters, Mar. Chem., 28, 89-107, 1989.

Rhoads, D. C.: Organism sediment relations on the muddy sea floor. Oceanographyand, Mar.

Biol.: an Annual review, 12, 263-300, 1974.

\section{Biogeochemical processes in sediments of the Manfredonia Gulf}

F. Spagnoli et al.

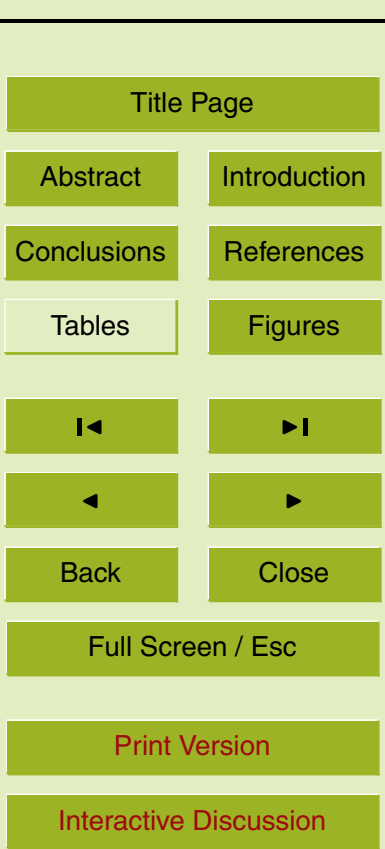




\section{BGD}

1, 803-823, 2004

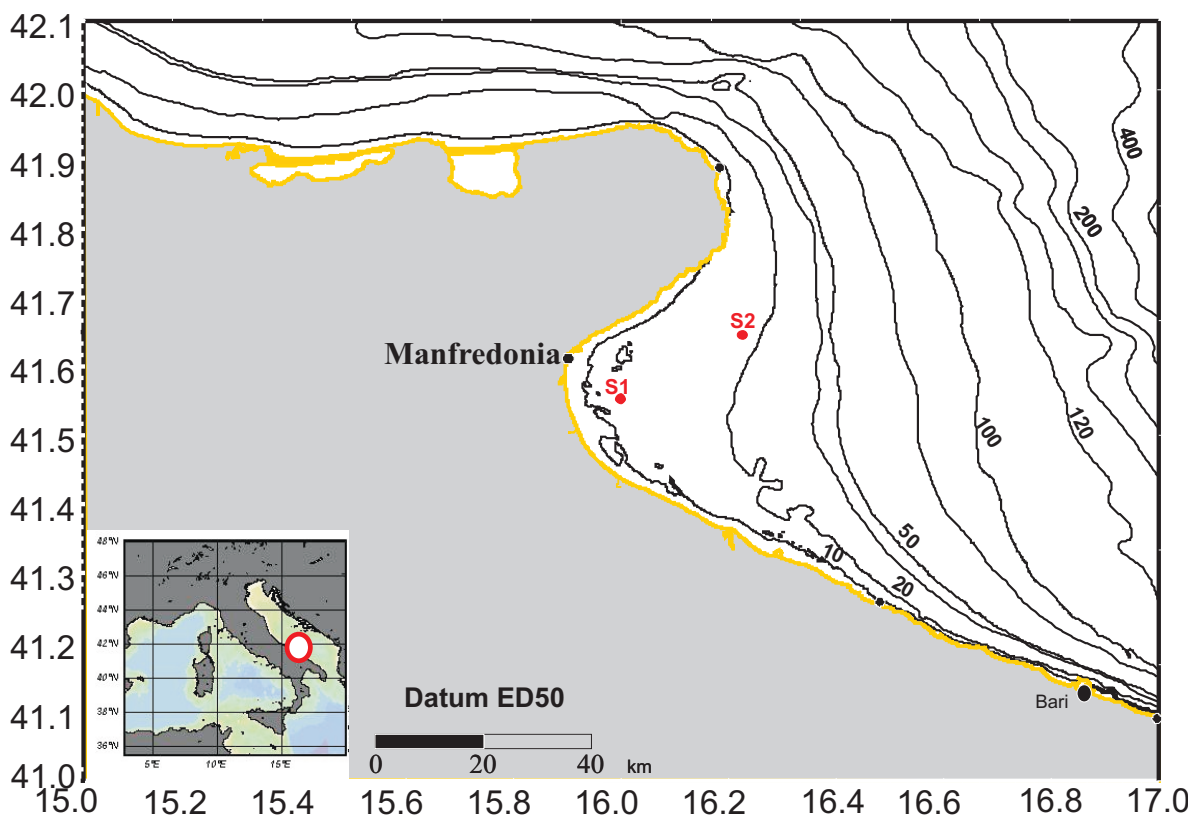

\section{Biogeochemical processes in sediments of the Manfredonia Gulf}

F. Spagnoli et al.

\section{Title Page}

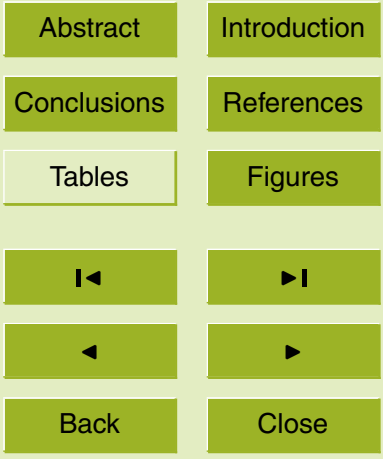

Full Screen / Esc

Fig. 1. Site map an stations location.

Print Version

Interactive Discussion

(C) EGU 2004 

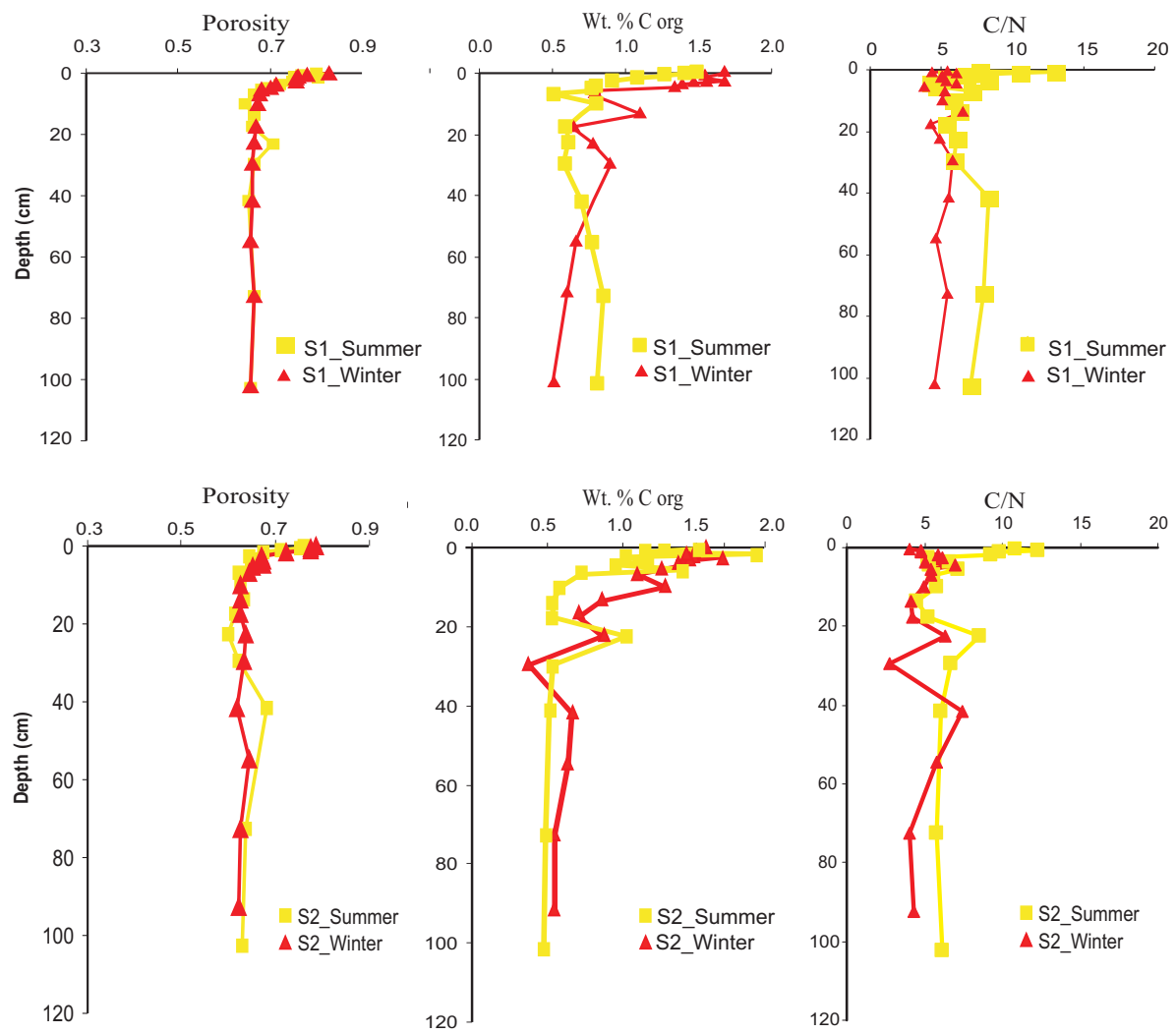

1, 803-823, 2004

Biogeochemical processes in sediments of the Manfredonia Gulf

F. Spagnoli et al.

Title Page

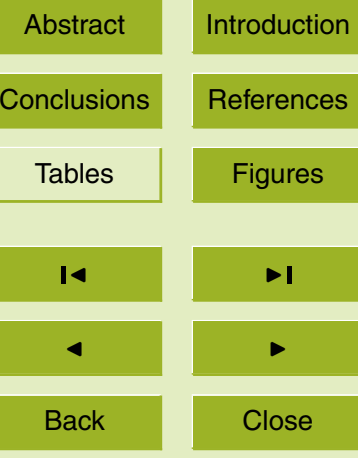

Full Screen / Esc

Print Version

Interactive Discussion

(C) EGU 2004 

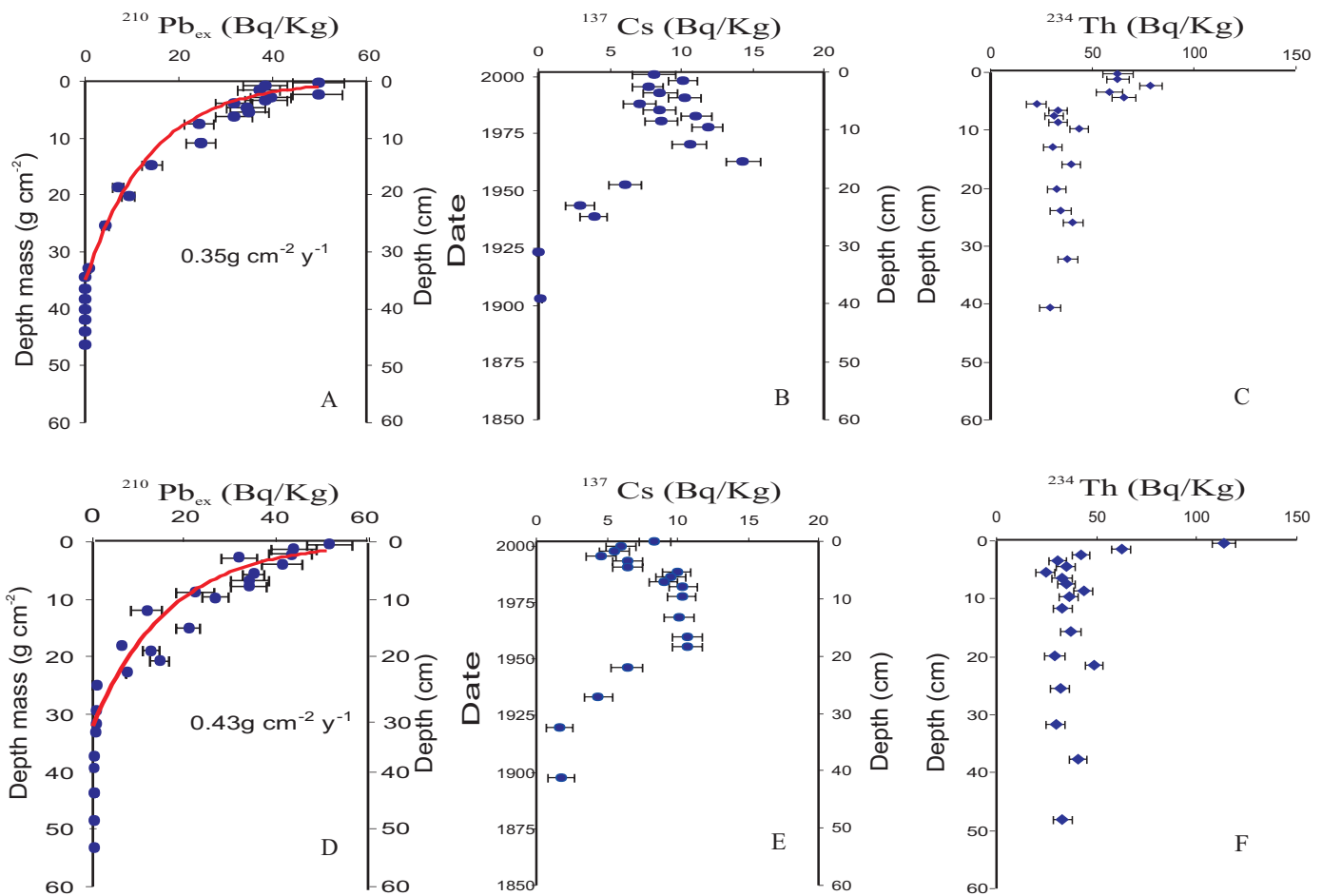

$\mathrm{Cs}(\mathrm{Bq} / \mathrm{Kg})$

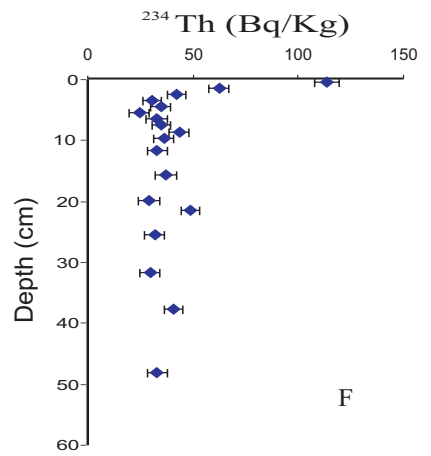

Fig. 3. Profiles of solid phase constituents at representative inshore (Sta. S1 (a), (b), (c)) and offshore (Sta. S2 (d), (e), (f)) stations. The solid red line shows the fit of an exponential function to excess $\mathrm{Pb}-210$ vs. mass depth.

\section{Biogeochemical processes in sediments of the Manfredonia Gulf}

F. Spagnoli et al.

\section{Title Page}

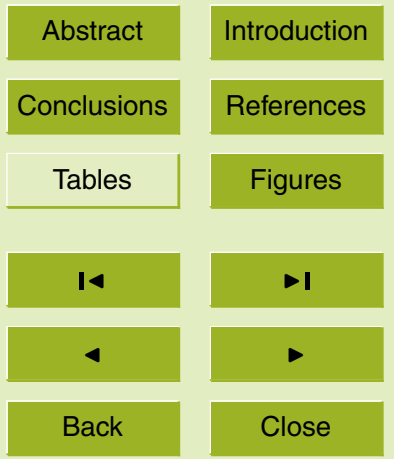

Full Screen / Esc

Print Version

Interactive Discussion

(c) EGU 2004 


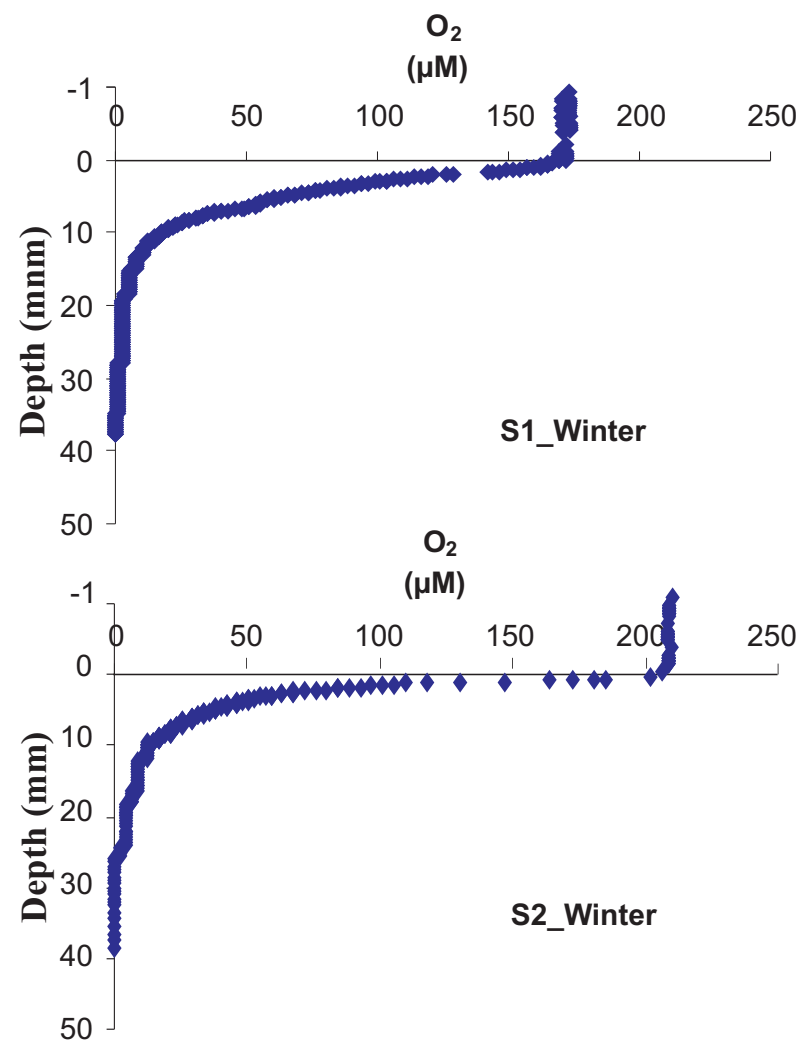

Fig. 4. Dissolved oxygen profiles in cores collected in winter cruise.
1, 803-823, 2004

Biogeochemical processes in sediments of the Manfredonia Gulf

F. Spagnoli et al.

Title Page

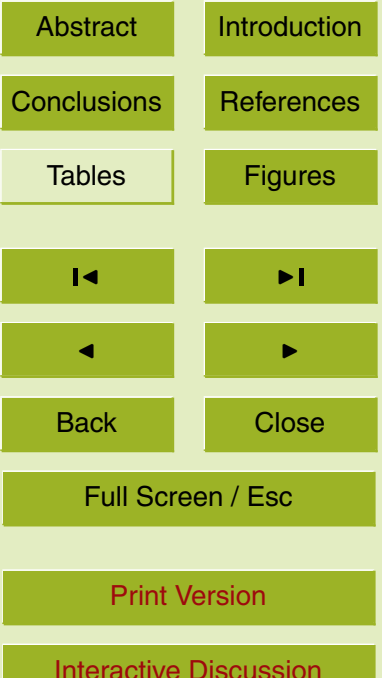

Interactive Discussion

(C) EGU 2004 

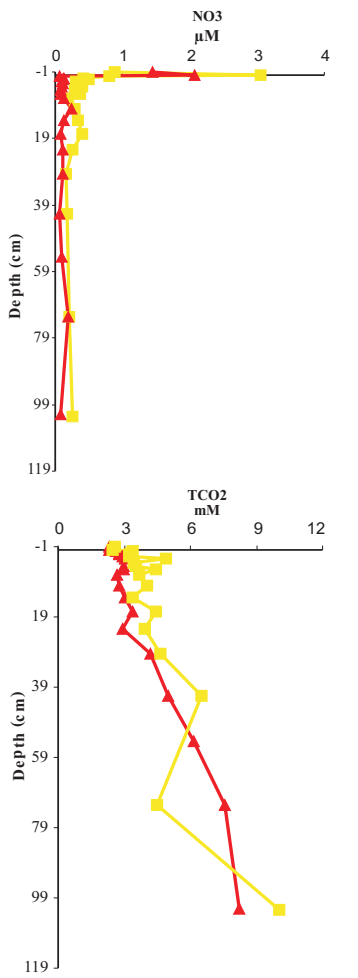
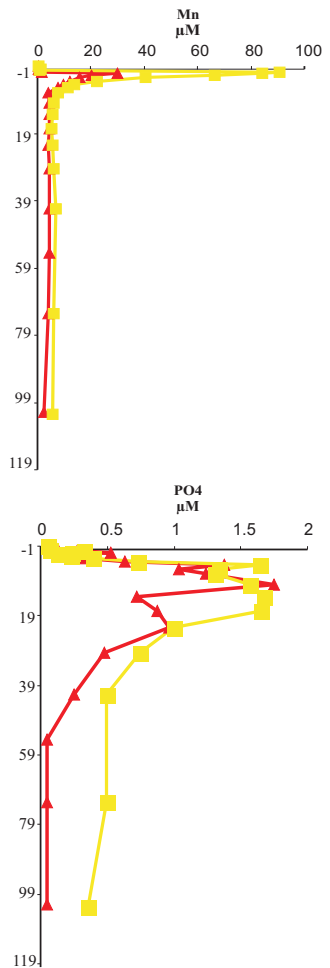
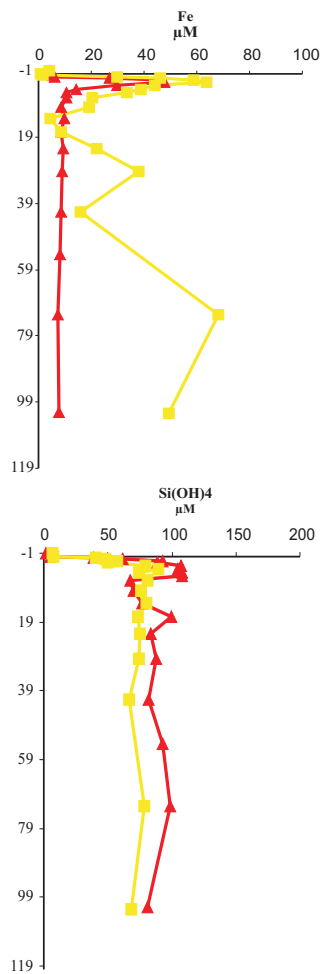
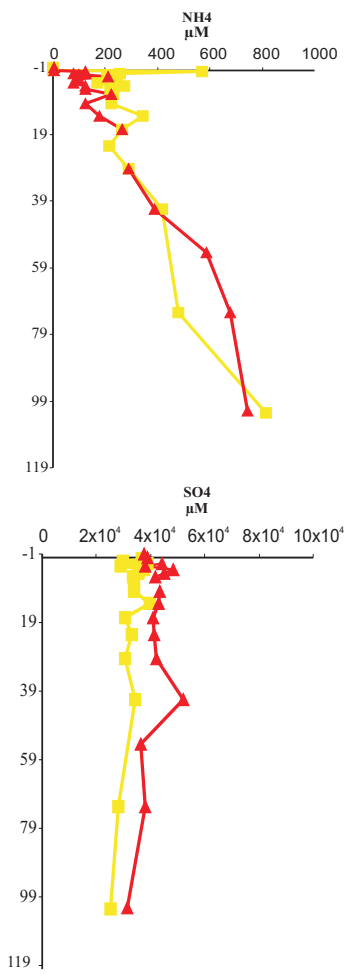

Fig. 5. (a) Pore water profiles of nutrients and $\mathrm{TCO}_{2}$ from cores colletcted in Gulf of Manfredonia in $\mathrm{S} 1$ station. Depth intervals were $0.5 \mathrm{~cm}$ for the first four points, $1 \mathrm{~cm}$ for the next 4 points, 3 and 5 for the subsequent point, data are plotted at the mid-point of the interval. Two season are identified by the different symbols (red triangle $=$ Winter, yellow square $=$ Summer). Points at -1 depth indicate bottom water values.

1, 803-823, 2004

Biogeochemical processes in sediments of the Manfredonia Gulf

F. Spagnoli et al.

\section{Title Page}

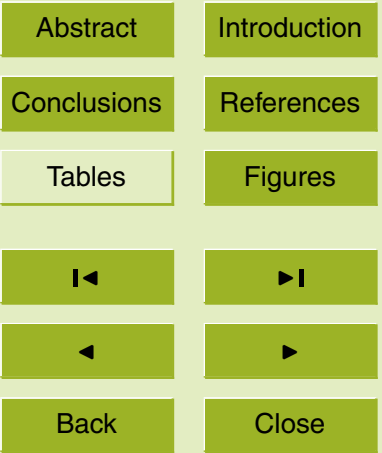

Full Screen / Esc

Print Version

Interactive Discussion 


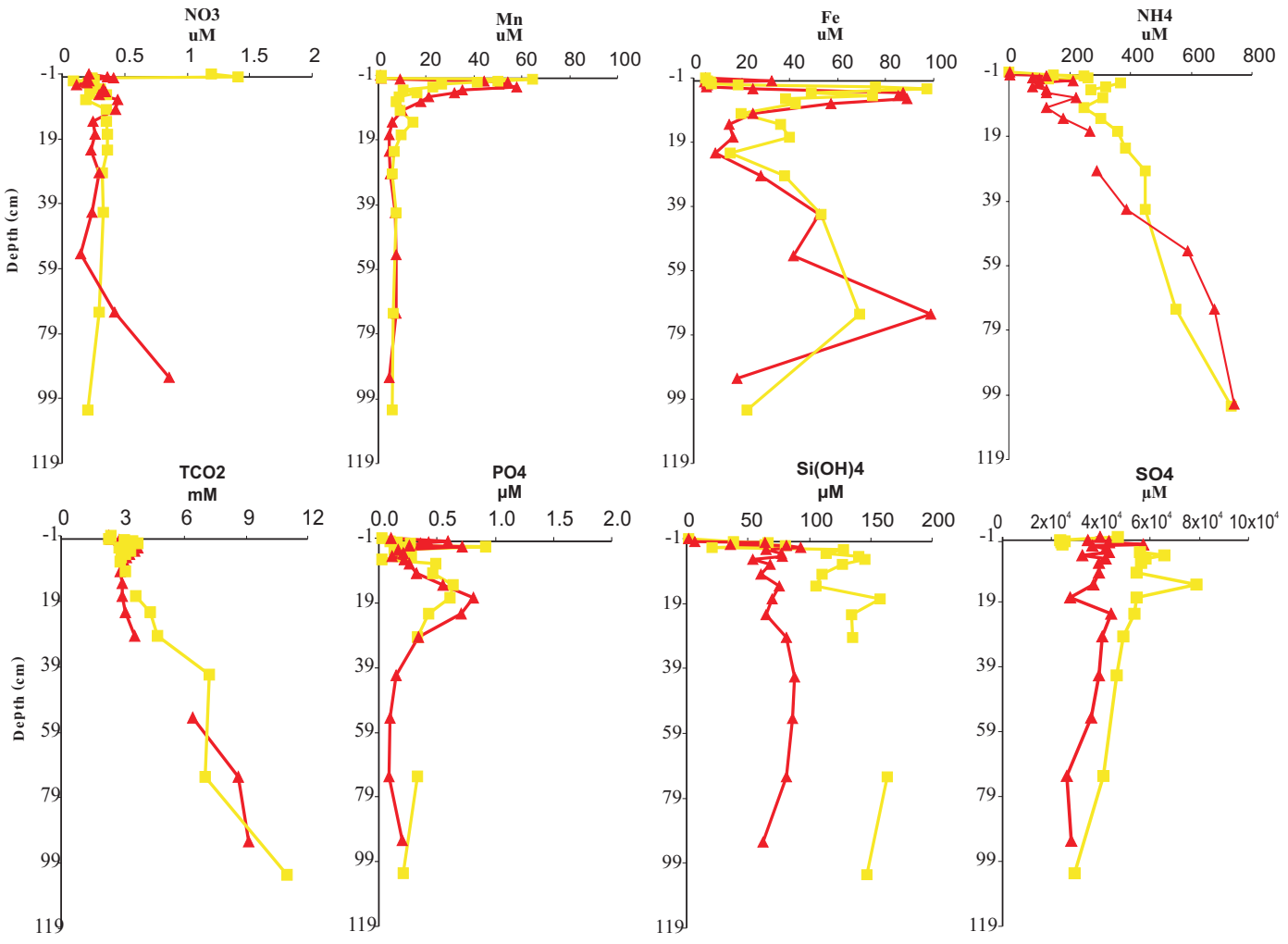

Fig. 5. (b) Pore water profiles of nutrients and $\mathrm{TCO}_{2}$ from cores colletcted in Gulf of Manfredonia in S2 station. Depth intervals were $0.5 \mathrm{~cm}$ for the first four points, $1 \mathrm{~cm}$ for the next 4 points, 3 and 5 for the subsequent point. data are plotted at the mid-point of the interval. Two season are identified by the different symbols (red triangle $=$ Winter, yellow square $=$ Summer). Points at -1 depth indicate bottom water values.
BGD

1, 803-823, 2004

Biogeochemical processes in sediments of the Manfredonia Gulf

F. Spagnoli et al.

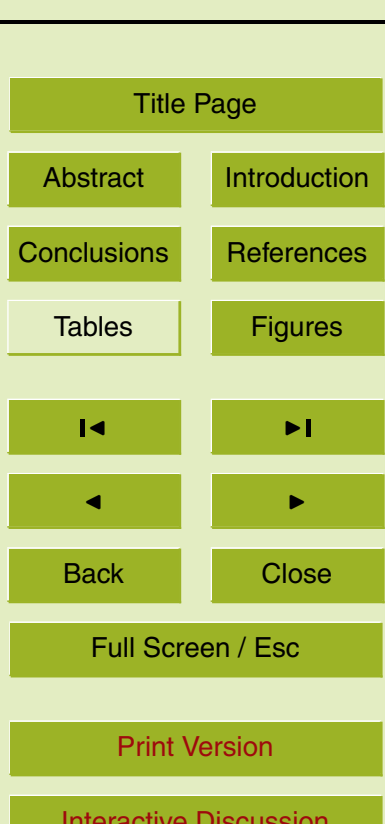

Interactive Discussion

(c) EGU 2004 
BGD

1, 803-823, 2004
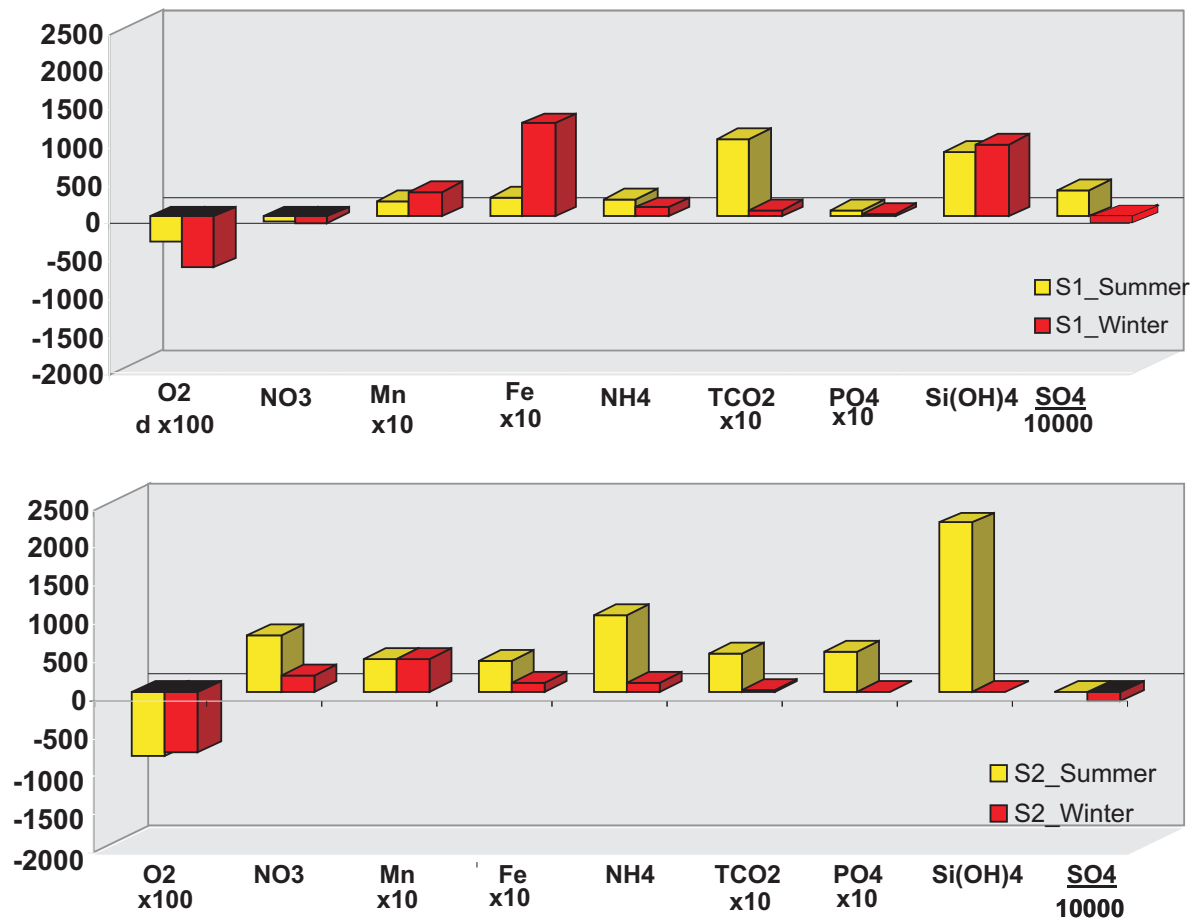

Fig. 6. Benthic fluxes of nutrients and $\mathrm{TCO}_{2}$ from deployments used in Gulf of Manfredonia in $\mathrm{S} 1$ and $\mathrm{S} 2$ station. Units are $\mu \mathrm{mol} \mathrm{m}{ }^{-2} \mathrm{~d}$ for nutrients and $\mathrm{mmol} \mathrm{m}^{-2} \mathrm{~d}$ for $\mathrm{O}_{2}$ and $\mathrm{TCO}_{2}$.

Title Page

\section{Biogeochemical processes in sediments of the Manfredonia Gulf}

F. Spagnoli et al.

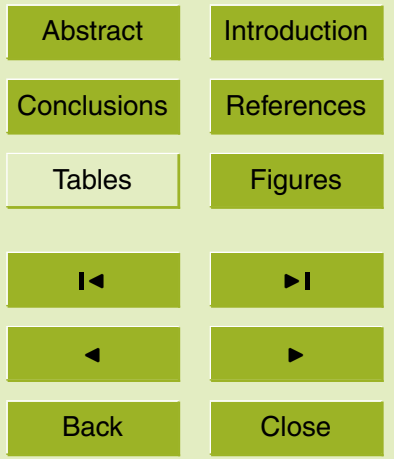

Full Screen / Esc

Print Version

Interactive Discussion

(C) EGU 2004 